Pure Sciences

Oral

Abstract ID: 148

\title{
Differential methods of cell lysis for protein profiling of Alexandrium sp. using 2D gel electrophoresis
}

Nurul Ashima Hamdan | Normawaty Mohammad-Nor | Shafida Abd. Hamid | Nor Hasniza Md. Zin | Noraslinda Muhamad Bunnori

Kulliyyah of Science, International Islamic University Malaysia

Introduction: Protein profiling of harmful algae is an ongoing study where the latest analysis was conducted on A. minutum. It is a fundamental study where the protein expression of targeted species can be used to understand the biochemical pathway of selected proteins. The Malaysia Alexandrium spp. has the potential to cause massive blooming that brings harm to the aquatic ecosystem. Methods: In this experiment three methods of cell lysis were tested against A. leei isolated from Malaysian waters. Results: The Axenic culture of the sample was established in enriched seawater media (ESDK) with 12 hours of light and 12 hours of dark conditions. The sample was extracted during exponential phase (day 18) where the same amount of cells was collected via centrifugation. The same buffer was used for each technique of cell lysis in order to get the best protein profiles in terms of a band or spot intensity and number. The cells of $A$. leei were lysed using sonication in the ice-cold water bath, sonication with probe and freeze-thawing followed by sonication in iced bath is the best method of protein extraction. Conclusions: Nevertheless, it can be concluded that the qualitative analysis using SDS-PAGE and 2D gel electrophoresis could be best method and the freeze thawing mode of cell lysis produced an excellent result among others as the protein spots produced were precise and less streaking were observed.

KEYWORDS: Alexandrium spp., protein profiling, Alexandrium leei, SDS Page, 2D Gel electrophoresis 